\title{
Particle export during a bloom of Emiliania huxleyi in the North-West European continental margin
}

\author{
S. Schmidt ${ }^{\text {a,b, } *}$, J. Harlay ${ }^{\text {c,d }}$, A.V. Borges ${ }^{\text {d }}$, S. Groom ${ }^{\text {e }}$, B. Delille ${ }^{\text {d }}$, N. Roevros ${ }^{\text {c }}$, S. Christodoulou ${ }^{\text {e, }}$ L. Chou ${ }^{\text {c }}$ \\ a CNRS-Université de Bordeaux, UMR5805 EPOC, F-33405 Talence Cedex, France \\ ${ }^{\mathrm{b}}$ Université de Bordeaux, UMR5805 EPOC, F-33405 Talence Cedex, France \\ c Laboratoire d'Océanographie Chimique et Géochimie des Eaux, Université Libre de Bruxelles, Belgium \\ ' Unité d'Océanographie Chimique, Université de Liège, Belgium \\ e Remote Sensing Group, Plymouth Marine Laboratory, UK
}

\section{A R T I C L E I N F O}

\section{Article history}

Received 29 September 2010

Received in revised form 12 July 2011

Accepted 5 December 2011

Available online 14 December 2011

\section{Keywords:}

Coccolithophores

North-Western European continental margin

La Chapelle Bank

Goban Spur

Thorium-234

POC flux

Particle

Residence time

\begin{abstract}
A B S T R A C T
Coccolithophores, the dominant pelagic calcifiers in the oceans, play a key role in the marine carbon cycle through calcification, primary production and carbon export, the main drivers of the biological $\mathrm{CO}_{2}$ pump. In May 2002 a cruise was conducted on the outer shelf of the North-West European continental margin, from the north Bay of Biscay to the Celtic Sea $\left(47.0^{\circ}-50.5^{\circ} \mathrm{N}, 5.0^{\circ}-11.0^{\circ} \mathrm{W}\right)$, an area where massive blooms of Emiliania huxleyi are observed annually. Biogeochemical variables including primary production, calcification, partial pressure of $\mathrm{CO}_{2}\left(\mathrm{pCO}_{2}\right)$, chlorophyll-a (Chl-a), particle load, particulate organic and inorganic carbon (POC, PIC) and ${ }^{234} \mathrm{Th}$, were measured in surface waters to assess particle dynamic and carbon export in relation to the development of a coccolithophore bloom. We observed a marked northward decrease in Chl-a concentration and calcification rates: the bloom exhibited lower values and may be less well developed in the Goban Spur area. The export fluxes of POC and PIC from the top $80 \mathrm{~m}$, determined using the ratios of POC and PIC to ${ }^{234} \mathrm{Th}$ of particles, ranged from 81 to $323 \mathrm{mg} \mathrm{C} \mathrm{m}^{-2} \mathrm{~d}^{-1}$ and from 30 to $84 \mathrm{mg} \mathrm{C} \mathrm{m}^{-2} \mathrm{~d}^{-1}$, respectively. The highest fluxes were observed in waters presenting a well-developed coccolithophore bloom, as shown by high reflectance of surface waters. This experiment confirms that the occurrence of coccolithophores promotes efficient export of organic and inorganic carbon on the North-West European margin.
\end{abstract}

(C) 2011 Elsevier B.V. All rights reserved.

\section{Introduction}

Coccolithophores, among which Emiliania huxleyi is the most abundant and widespread species, are considered to be the main productive calcifying organism on Earth and often form massive blooms in temperate and sub-polar oceans, in particular at continental margins and shelf seas (Brown and Yoder, 1994; Holligan et al., 1983; McIntyre and Be, 1967). Coccolithophores contribute to the export to depth of carbon by both primary production (PP) and calcification (CAL). PP, via photosynthesis in the photic zone and vertical export of organic matter to deep waters, draws down $\mathrm{CO}_{2}$ from surface waters. This is the so called "organic carbon pump". In contrast, CAL, formation of biogenic calcium carbonate $\left(\mathrm{CaCO}_{3}\right)$, leads to a thermodynamic shift of $\mathrm{HCO}_{3}^{-}$to $\mathrm{CO}_{2}$, hence, a release of $\mathrm{CO}_{2}$ to surrounding surface waters. This "carbonate counter-pump" counteracts the effect on $\mathrm{CO}_{2}$ fluxes of primary production and organic carbon export.

\footnotetext{
* Corresponding author at: UMR5805 EPOC, Université de Bordeaux 1, Avenue des Facultés, F-33405 Talence Cedex, France. Tel.: + 33540003 315; fax: + 33556840 848.

E-mail address: s.schmidt@epoc.u-bordeaux1.fr (S. Schmidt).
}

Often covering vast areas, blooms of the coccolithophore E. huxleyi act also as an important source of dimethyl sulphide (DMS) (Burkill et al., 2002), with possible consequences for cloud albedo and heat balance and alter the optical properties of the surface mixed layer (Groom and Holligan, 1987; Holligan et al., 1983). Their presence gives the ocean a milky white or turquoise appearance. Coccolithophores are further known to produce transparent exopolymer particles (TEP) that promote particle aggregation and related processes such as marine snow formation and sinking (Engel et al., 2009). In addition, due to its mineral ballast effect, biogenic calcium carbonate contributes to the export of organic carbon from surface ocean to deep waters. Coccolithophores are thus likely to play a key role in the global carbon, carbonate and sulphur cycles.

The main objective of this study was to explore particulate organic and inorganic carbon (POC, PIC) export during the development of a coccolithophore bloom. In May 2002, we sampled a transect from the La Chapelle Bank to Goban Spur $\left(47^{\circ}-50^{\circ} 30^{\prime} \mathrm{N}, 5^{\circ}-11^{\circ} \mathrm{W}\right)$ on the outer shelf of the North-West European margin. In this work, Thorium-234 $\left({ }^{234} \mathrm{Th}, \mathrm{t}_{1 / 2}=24.1\right.$ days $)$, a naturally occurring radionuclide, was used to quantify particulate fluxes and to assess the impact of coccolithophore blooming on the efficiency of POC and PIC export from upper waters to depth. 


\section{Material and methods}

\subsection{Cruise description}

The BG02/11 cruise on board RV Belgica was conducted in the North-West European margin from the northern limit of Bay of Biscay to the Celtic Sea (Fig. 1), a zone in which blooms of the coccolithophore E. huxleyi are frequently and recurrently observed (Brown and Yoder, 1994). We measured biogeochemical variables including $\mathrm{PP}, \mathrm{CAL}$, partial pressure of $\mathrm{CO}_{2}\left(\mathrm{pCO}_{2}\right)$, Chl-a, suspended particulate matter (SPM), POC, PIC, and ${ }^{234} \mathrm{Th}$, in 5 stations along a transect from south (La Chapelle Bank, $47^{\circ} 25^{\prime} \mathrm{N}$ ) to north (Goban Spur, $50^{\circ} 24^{\prime} \mathrm{N}$ ) of the outer continental shelf (Fig. 1). The southernmost station, 4, was located on the slope over the $2000 \mathrm{~m}$ contour; the others $(8,11,14,16)$ were located on the outer shelf at depths < $200 \mathrm{~m}$. These stations were visited successively within few days, from May 3 to 10, 2002: differences between the stations could be mainly ascribed to spatial, rather than temporal, changes. A Seabird conductivity-temperature-depth (CTD) probe equipped with a rosette sampler of 12 10-L Niskin bottles was used to determine depth profiles of temperature and salinity, and to collect discrete samples for chemical analyses.

\subsection{Pigments, SPM and POC concentrations}

Seawater $(0.25 \mathrm{~L})$ was filtered through glass fibre filters $(47 \mathrm{~mm}$ Whatman GF/F) and stored frozen before analysis at the laboratory. Pigment extraction was carried out overnight in $10 \mathrm{~mL} 90 \%$ acetone at $4{ }^{\circ} \mathrm{C}$ in the dark. Measurements of Chl-a and its main decay product, the phaeophytin-a (Phaeo-a) are performed with a Shimatzu RF-1501 spectrofluorometer.

For SPM, seawater (1-2 L) was filtered through $47 \mathrm{~mm}$ Nuclepore pre-weighted filters, rinsed with an isotonic solution and stored onboard at $-20{ }^{\circ} \mathrm{C}$. The filters were dried at $50{ }^{\circ} \mathrm{C}$ overnight and weighed with $0.01 \mathrm{mg}$ readability on an analytical scale (Sartorius). The concentration of SPM was determined as the ratio of the particle mass to the filtered volume.
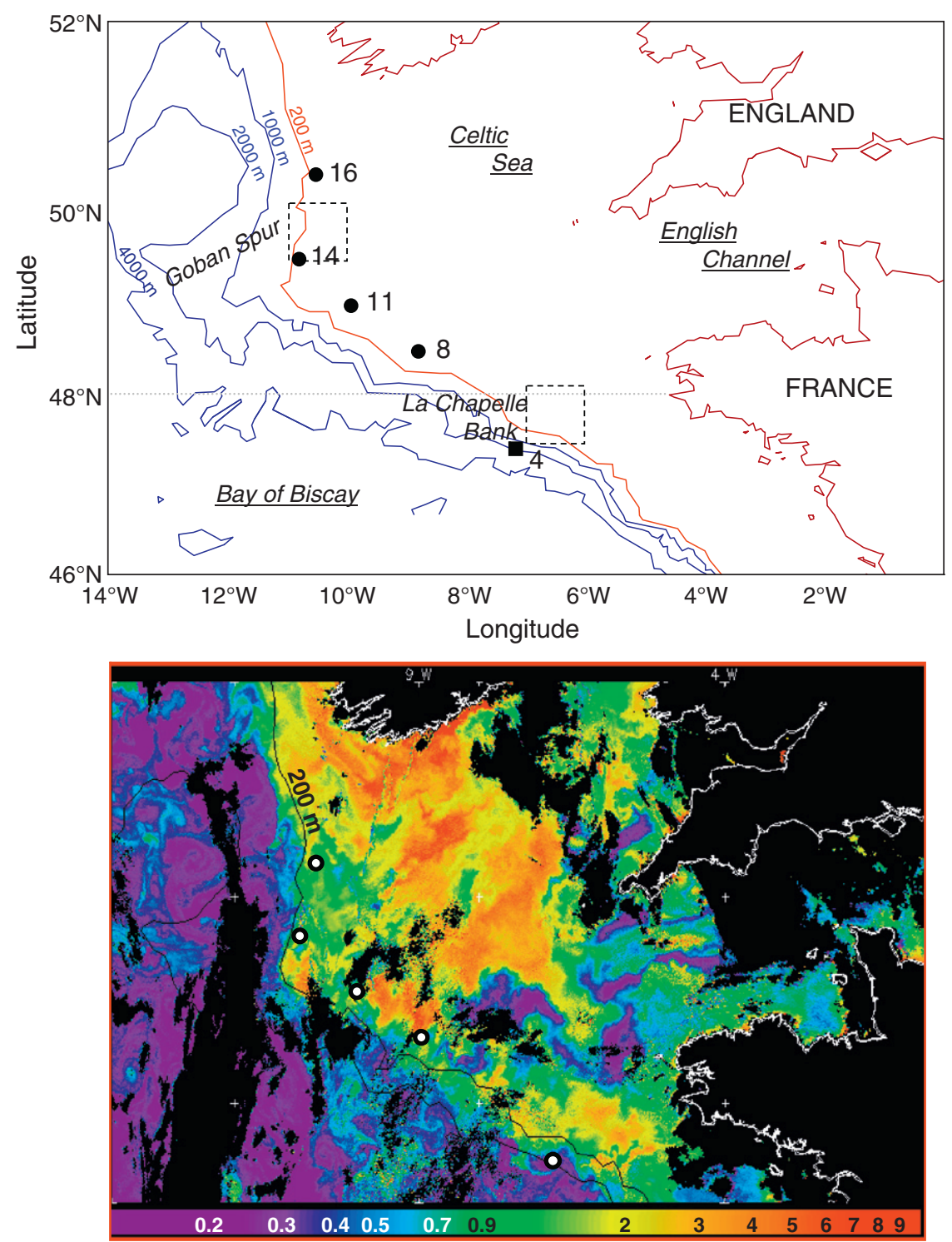

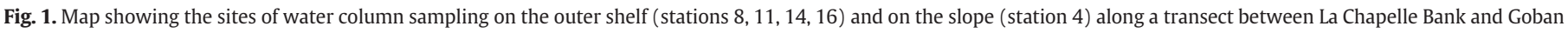

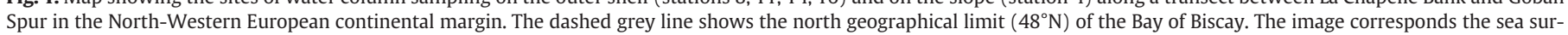
face chlorophyll-a distribution (composite of 5-6 May). The two squares show the two areas corresponding to time series data presented in Fig. 2. 


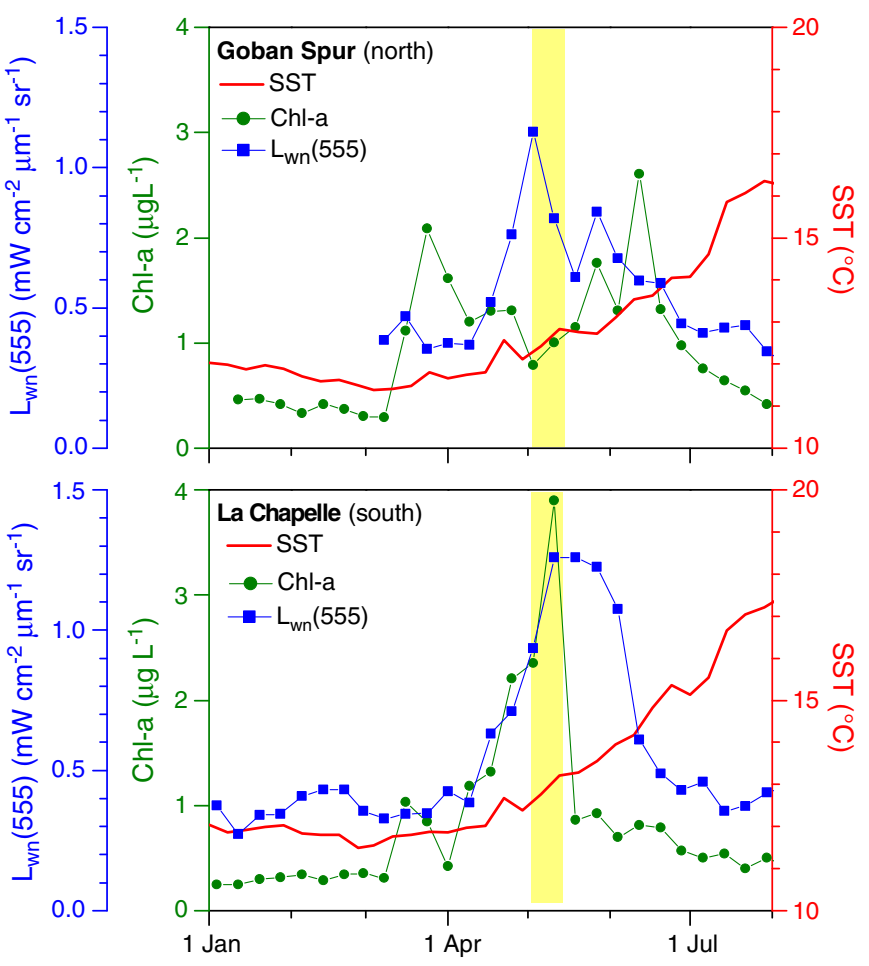

Fig. 2. Time series of 8-day area-averaged sea surface temperature (SST; blue line; ${ }^{\circ} \mathrm{C}$ ), chlorophyll-a (Chl-a; green circles; $\mu \mathrm{L} \mathrm{L}^{-1}$ ), and normalised water-leaving radiance at $555 \mathrm{~nm}$ (Ocean Color Time-Series Online Visualization and Analysis web site, Level-3 Sea-viewing Wide Field-of-view Sensor (SeaWiFS), http://reason.gsfc.nasa.gov/Giovanni/) ( $\mathrm{L}_{\mathrm{wn}}(555)$; blue squares; $\mathrm{mW} \mathrm{cm}^{-2} \mu \mathrm{m}^{-1} \mathrm{sr}^{-1}$ ) at La Chapelle Bank (lower panel; lat $\left[47.5^{\circ} \mathrm{N}, 48.0^{\circ} \mathrm{N}\right]$; long $\left[7.0^{\circ} \mathrm{W}, 6.0^{\circ} \mathrm{W}\right]$ ) and Goban Spur (upper panel; lat $\left[49.0^{\circ} \mathrm{N}\right.$, $\left.50.0^{\circ} \mathrm{N}\right]$; long $\left.\left[11.0^{\circ} \mathrm{W}, 10.0^{\circ} \mathrm{W}\right]\right)$ from January to July 2002 . The underline period corresponds to the BG02/11 cruise ( $2^{\mathrm{d}}$ leg; 3 to 11 May 2002).

For POC, seawater (1-2 L) was filtered on pre-combusted $47 \mathrm{~mm}$ $\mathrm{GF} / \mathrm{F}$ filters, stored onboard at $-20^{\circ} \mathrm{C}$. At the lab, the filters were dried overnight at $50{ }^{\circ} \mathrm{C}$. The filtered area was stamped out with a calibrated punch in order to randomly sub-sample six stamps per filter. One set of triplicate stamps was acidified overnight under $\mathrm{HCl}$ fumes, at room temperature, for POC analysis. Total particulate carbon (TPC) and POC were determined sequentially with a Fisons NA 2000 CHN micro-analyser. The difference between averaged TPC and POC allowed the determination of PIC.

\subsection{Primary production, calcification and air-sea $\mathrm{CO}_{2}$ fluxes}

The rate of $\mathrm{C}$ fixation was estimated from the incorporation of $\mathrm{H}^{14} \mathrm{CO}_{3}$. In brief, sterile $0.25 \mathrm{~L}$ culture flasks filled with radioisotopically labelled seawater were incubated for about $6 \mathrm{~h}$ in a linear incubator reproducing a gradient of irradiance ranging between 5 and $400 \mu \mathrm{mol}$ photons $\mathrm{m}^{-2} \mathrm{~s}^{-1}$. During incubation, samples were kept at SST with pumped seawater circulating continuously through the incubator. The incorporation was stopped by filtration of $2 \times 0.125 \mathrm{~L}$ on $25 \mathrm{~mm}$ GF/F glass fibre filters at very low vacuum. One filter was left untreated and the other was acidified, and stored frozen in $20 \mathrm{~mL}$ scintillation vials until radioactivity measurement in the laboratory by liquid scintillation counting. The acidified samples were measured for radioactivity to quantify the incorporation of ${ }^{14} \mathrm{C}$ in the POC phase (PP). The amount of inorganic ${ }^{14} \mathrm{C}$ incorporated into PIC (CAL) was obtained by the difference between total ${ }^{14} \mathrm{C}$ incorporation and PP. Primary production and calcification were integrated on a daily basis over the water column (see Harlay et al., 2010, for details).

Air-sea $\mathrm{CO}_{2}$ fluxes were calculated from measurements of $\mathrm{pCO}_{2}$ according to Suykens et al. (2010).

\section{4. ${ }^{234}$ Th activities}

Immediately after sampling, 20-L seawater was passed through a $0.7 \mu \mathrm{m}$ pore size filter to separate dissolved from particulate phases. Within one month after the collection, particulate ${ }^{234} \mathrm{Th}\left({ }^{234} \mathrm{Th}^{\mathrm{P}}\right)$ was directly measured on the filter by $\gamma$ counting. Isolation and purification of dissolved ${ }^{234} \mathrm{Th}\left({ }^{234} \mathrm{Th}^{\mathrm{D}}\right)$ were carried out on board a ship within $24 \mathrm{~h}$ after seawater collection, using an anion-exchange procedure. Activities of ${ }^{234} \mathrm{Th}$ and chemical efficiencies, based on ${ }^{229} \mathrm{Th}$, were determined in the lab using a single $\gamma$-counting (Rutgers van der Loeff et al., 2006; Schmidt and Reyss, 2000). Standards used for the calibration of the $\gamma$ detector were International Atomic Energy Agency reference materials (RGU-1). Uncertainties of ${ }^{234} \mathrm{Th}$ activities were calculated for each sample by propagation of the statistical errors from $\gamma$-counting. Precision estimates were variable, reflecting the counting rate of each sample, which depends on the chemical efficiency (between 30 and 60\%), and the decay of the initial ${ }^{234} \mathrm{Th}$ activity (between 30 and 80\%). As a result, propagated $1 \sigma$ errors range between 5 and $20 \%$ for the particulate phase, and between 5 and $15 \%$ for the dissolved phase. Total ${ }^{234} \mathrm{Th}\left({ }^{234} \mathrm{Th}^{\mathrm{T}}\right)$ represents the sum of dissolved and particulate ${ }^{234} \mathrm{Th}$ activities; error on ${ }^{234} \mathrm{Th}^{\mathrm{T}}$ is calculated by propagation of errors on ${ }^{234} \mathrm{Th}^{\mathrm{P}}$ and ${ }^{234} \mathrm{Th}^{\mathrm{D}}$. Errors in export fluxes and particle residence times were based on propagated methodological uncertainties.

During the cruise, the salinity of the upper $100 \mathrm{~m}$ depth showed a narrow range, from 35.48 to 35.61 , resulting in mean calculated ${ }^{238} \mathrm{U}$ of $2.51 \mathrm{dpm} \mathrm{L}^{-1}$, based on the U-Salinity relationship (Rutgers van der Loeff et al., 2006).

\section{Results and discussion}

\subsection{Hydrological and biological context during the experiment}

3.1.1. Time series of 8-day averaged remotely sensed SST, Chl-a and normalised water leaving radiance at $555 \mathrm{~nm}\left(L_{w n}(555)\right)$ from January to July, 2002

We used remotely sensed data of SST, Chl-a and $\mathrm{L}_{\mathrm{wn}}(555)$ to describe the main trends of hydrology and bloom development of phytoplankton and coccolithophore at the La Chapelle Bank and Goban Spur areas, the southern and northern boundaries of the investigated transect, in the first half of 2002 (the BG02/11 cruise was early May). Remotely sensed Chl-a is used as an indicator of the phytoplankton biomass in surface waters. E. huxleyi blooms can be distinguished by satellite imagery due to the high reflectance signal produced by the detached coccoliths, as observed in the North Atlantic waters (Groom and Holligan, 1987; Holligan et al., 1983, 1993).

SST increased gradually from $\sim 12^{\circ} \mathrm{C}$, the typical winter values, from January to March to around $17^{\circ} \mathrm{C}$ in July 2002 (Fig. 2). The increase in SST was more pronounced at the La Chapelle Bank, and surface waters at the Goban Spur area were $1{ }^{\circ} \mathrm{C}$ colder.

The time series of remotely sensed Chl-a showed the onset of the spring bloom in March: concentration increased from low winter levels $\left(<0.3 \mu \mathrm{g} \mathrm{L}^{-1}\right)$ to 1.0 and $2.0 \mu \mathrm{g} \mathrm{L}{ }^{-1}$ at the southern and northern locations, respectively (Fig. 2). Thereafter, the two areas exhibited distinct temporal evolutions, maybe related to the differences in SST. At the La Chapelle Bank, surface Chl-a increased rather continuously up to $3.9 \mu \mathrm{g} \mathrm{L}^{-1}$ in May. This peak was then followed by a strong decrease $\left(<1.0 \mu \mathrm{g} \mathrm{L}{ }^{-1}\right)$ from mid-May through summer. At the Goban Spur, phytoplankton biomass decreased gradually, from 2.0 to $1.2 \mu \mathrm{g} \mathrm{L}^{-1}$, through April to reach almost double the winter values in early May. A second peak was recorded in June, followed by a rapid decrease through summer. During the cruise in early May, surface Chl-a concentrations were thus higher in the southern part of the transect.

The increase in Chl-a from April onwards at the La Chapelle area was paralleled by a strong increase in $\mathrm{L}_{\mathrm{wn}}(555)$ (Fig. 2). Thereafter, 
$\mathrm{L}_{\mathrm{wn}}(555)$ stayed close to its highest level $\left(1.2 \mathrm{~mW} \mathrm{~cm}^{-2} \mu \mathrm{m}^{-1} \mathrm{sr}^{-1}\right)$ from May until end of June 2002. If one considers the $L_{w n}(555)$ threshold of $0.5 \mathrm{~mW} \mathrm{~cm}^{-2} \mu \mathrm{m}^{-1} \mathrm{sr}^{-1}$ as the optical signature of the coccolithophore bloom, this bloom had begun in surface waters of La Chapelle area in mid April 2002 and persisted for two months. The simultaneous SST increase was likely associated to stratification of the upper water column and warming through solar heating. Such thermal conditions favour the development of coccolithophore blooms when incoming irradiance is high (Nanninga and Tyrrell, 1996). The coccolithophore bloom declined in July as its signature faded to initial levels $\left(<0.5 \mathrm{~mW} \mathrm{~cm}{ }^{-2} \mu \mathrm{m}^{-1} \mathrm{sr}^{-1}\right)$. At the Goban Spur, the timing, and to a lesser extent the magnitude, of the coccolithophore signature in surface waters were similar: there was a rapid increase of $\mathrm{L}_{\mathrm{wn}}(555)$ in mid-April to values of about $1.0 \mathrm{~mW} \mathrm{~cm}{ }^{-2} \mu \mathrm{m}^{-1} \mathrm{sr}^{-1}$. However, as this signature persisted at La Chapelle, it decreased more rapidly in Goban Spur area, along with low Chl-a concentrations in surface waters.

Based on the remotely sensed time series, we established that the cruise was carried out during a period of high standing stock of coccolithophores at La Chapelle, and of peak to declining conditions in phytoplankton at Goban Spur.

\subsubsection{Temperature, salinity and photosynthetic pigments in the upper water column during the BG02/11 cruise}

In early May 2002, salinity exhibited negligible changes, between 35.5 and 35.6, in the top $100 \mathrm{~m}$ (Fig. 3a). Surface temperature ranged between $12.1{ }^{\circ} \mathrm{C}$ and $13.3^{\circ} \mathrm{C}$ (Fig. 3a; Table 1), in good agreement with remotely sensed values (Fig. 2). The stratification of the upper mixed layer was different from one location to another between $20 \mathrm{~m}$ (station 11) and $40 \mathrm{~m}$ (station 8), in contrast with the relatively well mixed conditions over the slope (station 4 ).

Vertical profiles of Chl-a suggest that phytoplankton was mainly present in the top of the water column (Fig. 3b). Measured Chl-a concentrations in surface waters were in good agreement with the remotely sensed values during the period of the cruise (Fig. 2). Over the continental slope, surface Chl-a never exceeded $1.0 \mu \mathrm{g} \mathrm{L}{ }^{-1}$ (station 4). The highest values were measured on the southern area of the outer shelf, up to $3.2 \mu \mathrm{g} \mathrm{L}^{-1}$ at stations 8 and 11 , compared to the northern area, up to $2.0 \mu \mathrm{L} \mathrm{L}^{-1}$ (Fig. 3b).

Phaeopigment concentrations were low, $<0.2 \mu \mathrm{g} \mathrm{L} \mathrm{L}^{-1}$, in surface layers whatever the station (Fig. 3b). Over the slope, station 4 displayed low Phaeo-a/Chl-a ratio $(<0.5)$ in the upper $100 \mathrm{~m}$ depth. On the opposite, shelf stations displayed in depth higher or similar Phaeo-a concentrations compared to Chl-a, as indicated by Phaeo/ Chl-a ratio $>1$. This higher contribution of Phaeo-a to the pool of phytoplankton pigments may indicate a general trend towards ageing of the spring bloom. Below $40 \mathrm{~m}$, this pattern may be associated with the settling of biomass from the surface layer. Hence, the shift from the initial diatom bloom towards a coccolithophore-dominated situation was probably accompanied by the sinking of "old" diatoms, over the continental shelf and their replacement in the surface layer by "new" coccolithophores. Over the slope a new phytoplankton population started blooming at station 4 .

\subsection{Primary production, calcification and air-sea $\mathrm{CO}_{2}$ fluxes}

Primary production values ranged between 320 and $1010 \mathrm{mg} \mathrm{C} \mathrm{m}^{-2} \mathrm{~d}^{-1}$ (Table 1$)$. On the outer shelf, PP rates roughly decreased northward: from 1010 (station 8) to 500 (station 16) $\mathrm{mg} \mathrm{C} \mathrm{m}{ }^{-2} \mathrm{~d}^{-1}$. In parallel, CAL rates also decreased from $320 \mathrm{mg} \mathrm{C} \mathrm{m}^{-2} \mathrm{~d}^{-1}$ (station 8) to very low levels ( $10 \mathrm{mg} \mathrm{C} \mathrm{m}^{-2} \mathrm{~d}^{-1}$ ) at station 16 (Fig. 4). The PP and CAL values over the continental shelf are within the broad range of rates determined during coccolithophore blooms in the Celtic Sea or in the North Atlantic (Fernández et al., 1993; Harlay et al., 2010; Joint et al., 2001).
The $\mathrm{pCO}_{2}$ values at the four shelf stations varied within a narrow range (Table 1) and were below atmospheric equilibrium ( $372 \mathrm{ppm})$. The resulting air-sea $\mathrm{CO}_{2}$ fluxes ranged between -120 and $-170 \mathrm{mg} \mathrm{C} \mathrm{m}^{-2} \mathrm{~d}^{-1}$, as previously reported in the area at the same time of the year (Padin et al., 2009; Robertson et al., 1994; Suykens et al., 2010). Despite the high calcification rates (Table 1), the release of $\mathrm{CO}_{2}$ to the water column due to the precipitation of $\mathrm{CaCO}_{3}$ did not overcome the effect of $\mathrm{CO}_{2}$ uptake from the water column related to PP. Hence, the area acted as a sink for atmospheric $\mathrm{CO}_{2}$, in general agreement with the analysis of $\mathrm{CO}_{2}$ dynamics in the area during coccolithophore blooms (Suykens et al., 2010).

\subsection{Concentration and composition of SPM}

Suspended particulate matter was quantitatively more abundant over the continental shelf, with values ranging from 0.5 to $1.0 \mathrm{mg} \mathrm{L}^{-1}$ at the surface, than on the slope (station 4 ) where surface concentrations were less than $0.4 \mathrm{mg} \mathrm{L}^{-1}$ (Fig. 3b). POC in surface waters present also the same trend with higher concentrations, between 90 and $240 \mu \mathrm{g} \mathrm{C} \mathrm{L}{ }^{-1}$, on the shelf. PIC concentrations were markedly lower than POC, from 50 to $100 \mu \mathrm{C} \mathrm{L} \mathrm{L}^{-1}$ on the continental shelf to $<50 \mu \mathrm{g} \mathrm{C} \mathrm{L}{ }^{-1}$ over the slope (Fig. 3c). The POC and PIC values were within the range reported during coccolithophore blooms in the North Atlantic waters (48-336 $\mu \mathrm{g} \mathrm{C} \mathrm{L}{ }^{-1}$ and $27-300 \mu \mathrm{g} \mathrm{C} \mathrm{L}{ }^{-1}$ respectively; reviewed by Harlay et al., 2010). Surface PIC/POC molar ratios were comprised between 0.4 and 0.6 , higher than reported in the North Sea for an early-bloom situation $(<0.25$; Marañon and González, 1997).

\section{4. ${ }^{234}$ Th distribution and fluxes in the upper waters}

On the shelf, total ${ }^{234} \mathrm{Th}\left({ }^{234} \mathrm{Th}^{\mathrm{T}}\right)$ profiles were quite similar with deficits in the upper $50-70 \mathrm{~m}$. Deeper, equilibrium state between ${ }^{234} \mathrm{Th}^{\mathrm{T}}$ and ${ }^{238} \mathrm{U}$ was usually achieved. Station 8 presented the highest deficiencies (43\%) in the upper $20 \mathrm{~m}$. Such profiles are typical of a situation presenting a bloom development associated with an efficient export of particles from the upper surface waters (Schmidt et al., 2002b). Only station 14 showed ${ }^{234} \mathrm{Th}^{\mathrm{T}}$ close to the equilibrium with ${ }^{238} \mathrm{U}$, with a mean deficit of about $11 \%$, underlining a limited particle export of ${ }^{234} \mathrm{Th}$ to deeper layers. On the slope, station $4 \mathrm{ex}-$ hibited a quite different pattern: ${ }^{234} \mathrm{Th}$ activities were always lower than ${ }^{238} \mathrm{U}$, with deficiencies between 20 and $30 \%$. At $80 \mathrm{~m}$, the deepest depth of the profile, ${ }^{234} \mathrm{Th}^{\mathrm{T}}$ was not yet in equilibrium with ${ }^{238} \mathrm{U}$ : this deep deficit could be partly ascribed to the deep mixed layer recorded at station 4 . In addition, the Phaeo-a/Chl-a ratio (Section 3.1.2) indicated a new phytoplankton population started blooming at station 4 . The pronounced and deep deficit of ${ }^{234} \mathrm{Th}^{\mathrm{T}}$ at station 4 could thus result from a cumulative effect: the "memory" of an export event in April, and an upturn in particulate export associated with the bloom at the time of the cruise.

Particulate ${ }^{234} \mathrm{Th}$ ranged between 0.1 and $0.7 \mathrm{dpm} \mathrm{L}^{-1}$, representing $9-31 \%$ of ${ }^{234} \mathrm{Th}^{\mathrm{T}}$ activities. In fact, the highest concentrations of ${ }^{234} \mathrm{Th}^{\mathrm{P}}$ are observed in the upper $30 \mathrm{~m}$ water column, as previously reported for SPM and POC. As a result, $\mathrm{POC} /{ }^{234} \mathrm{Th}^{\mathrm{P}}$ ratios in surface waters presented some variability, from 10 to $27 \mu \mathrm{mol} \mathrm{dpm}^{-1}$; the highest ratios were measured at station 8 (Fig. 4), which exhibited also the highest primary production rate and integrated Chl-a content. Below $40 \mathrm{~m}, \mathrm{POC} /{ }^{234} \mathrm{Th}^{\mathrm{P}}$ ratios were lower (5 to $15 \mu \mathrm{mol} \mathrm{dpm}^{-1}$ ). This could be related to a reduction of the biomass content with depth and to some degradation of organic material, as indicated by Phaeo-a/Chl-a ratio $>1$ for shelf stations. $\mathrm{POC} /{ }^{234} \mathrm{Th}^{\mathrm{P}}$ ratios ranged from 4 to $27 \mu \mathrm{mol} \mathrm{dpm}{ }^{-1}$ (Fig. 4), as usually reported in surface waters (Buesseler et al., 2006). By comparison, $\mathrm{PIC} /{ }^{234} \mathrm{Th}^{\mathrm{P}}$ ratios

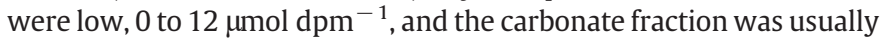
negligible at depth (Fig. 3c). 
a

Station 4

Temperature $\left({ }^{\circ} \mathrm{C}\right)$

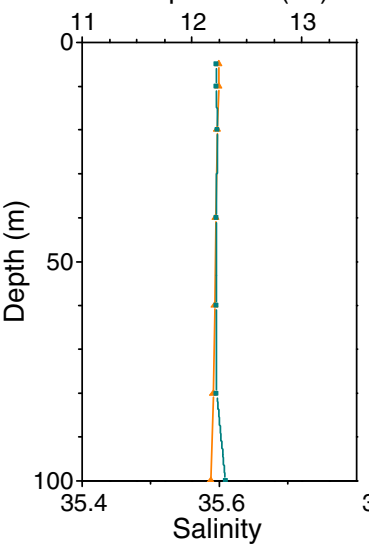

b

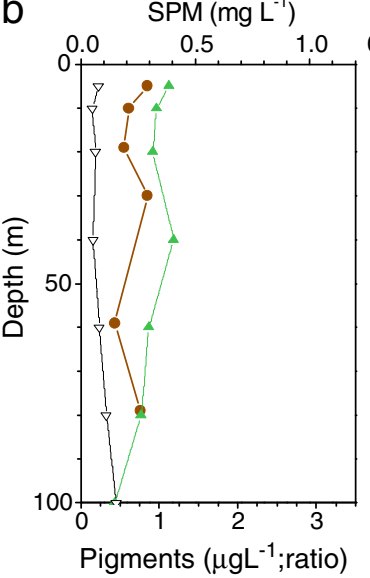

Station 8

Temperature $\left({ }^{\circ} \mathrm{C}\right)$

Station 11

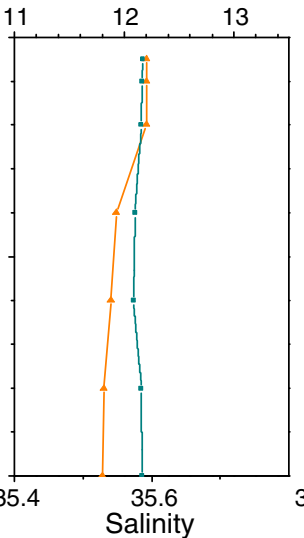

SPM ( $\left.\mathrm{mg} \mathrm{L}^{-1}\right)$
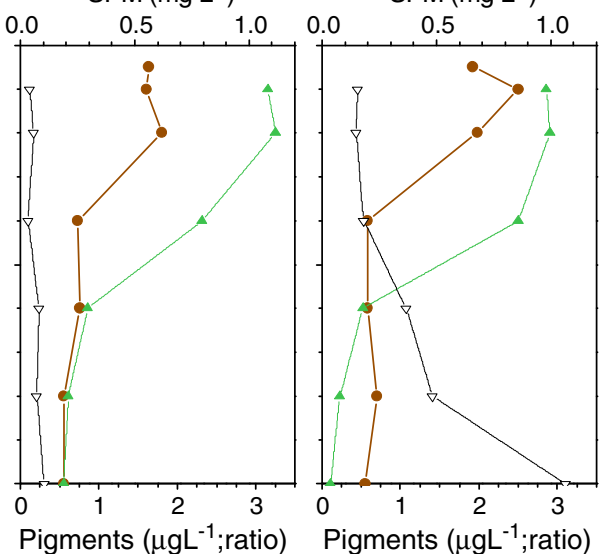

Pigments $\left(\mu \mathrm{gL}^{-1}\right.$;ratio)
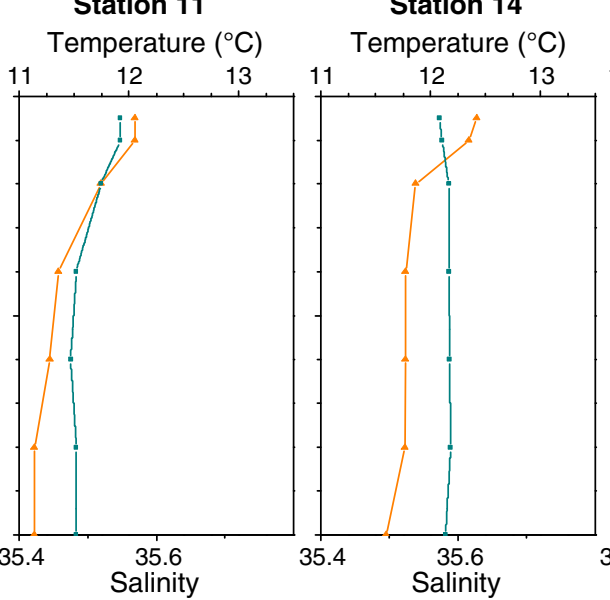

Station 16

Temperature $\left({ }^{\circ} \mathrm{C}\right)$

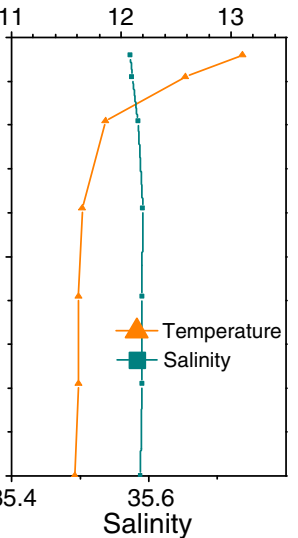

SPM (mg L $\left.{ }^{-1}\right)$

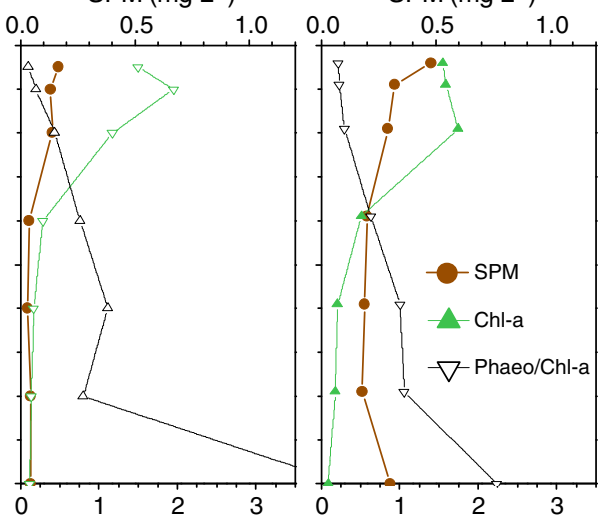

Pigments $\left(\mu \mathrm{gL}^{-1}\right.$;ratio)

C
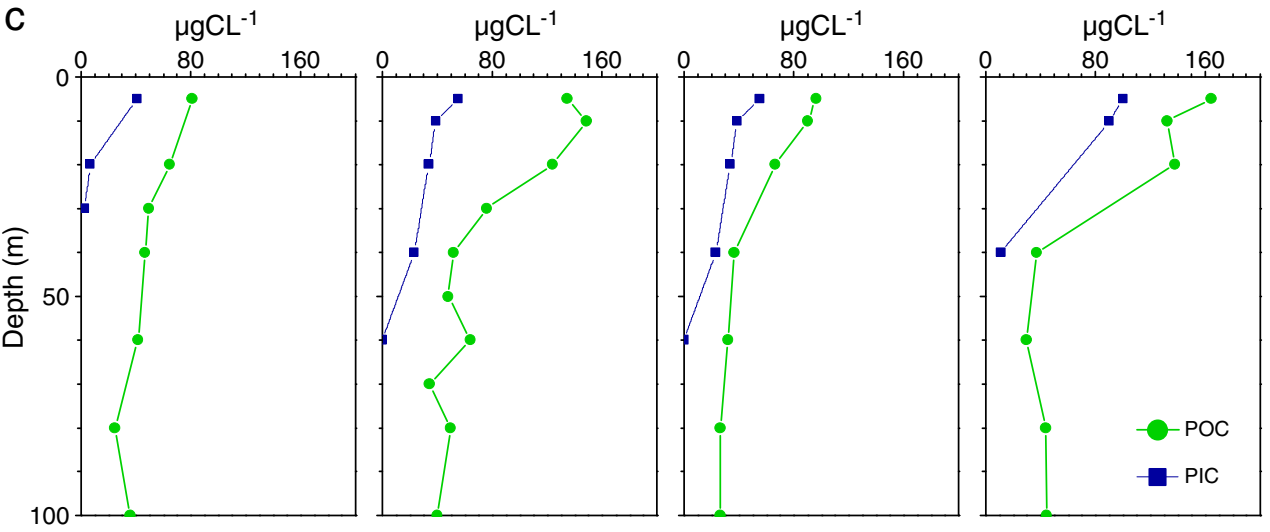

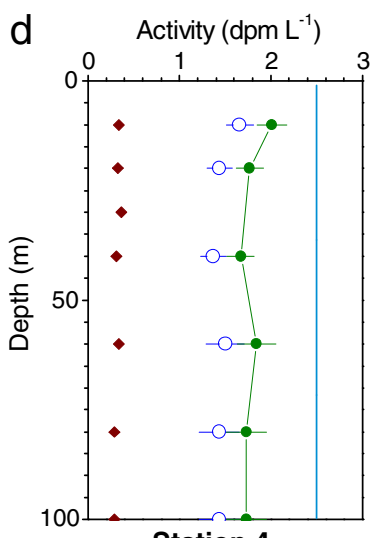

Station 4

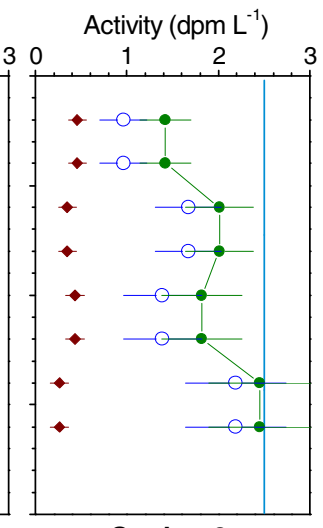

Station 8

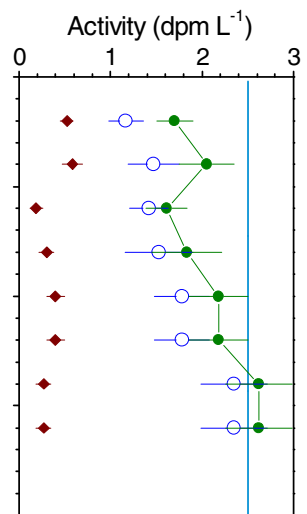

Station 11

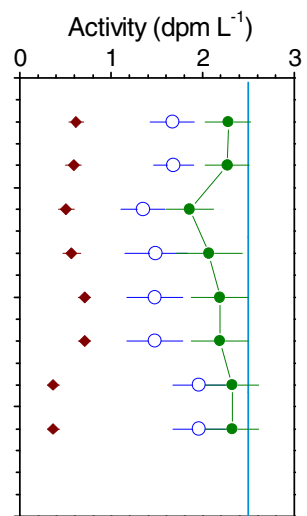

Station 14
Activity (dpm L ${ }^{-1}$ )

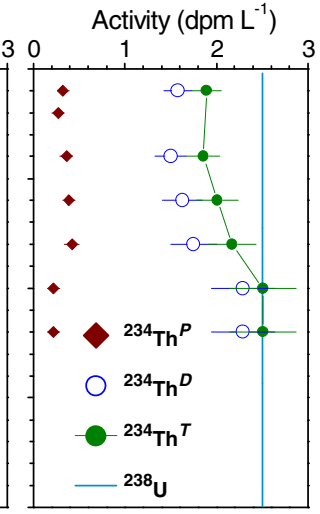

Station 16 
Table 1

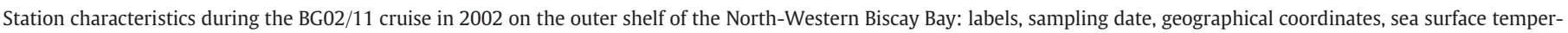

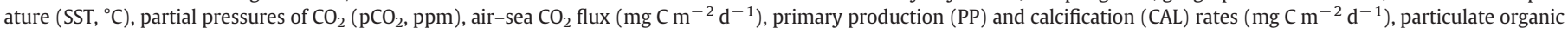
$\left(\mathrm{POC}^{\mathrm{Th}}\right)$ and inorganic $\left(\mathrm{PIC}^{\mathrm{Th}}\right)$ export fluxes $\left(\mathrm{mg} \mathrm{C} \mathrm{m}^{-2} \mathrm{~d}^{-1}\right)$, ratio of POC export derived from ${ }^{234} \mathrm{Th}$ to primary production (ThE,\%) and particle residence times ( $\mathrm{T}^{\mathrm{P}}$, day).

\begin{tabular}{|c|c|c|c|c|c|c|}
\hline Station & & 4 & 8 & 11 & 14 & $16^{\mathrm{a}}$ \\
\hline Date & 2002 & May 4 & May 7 & May 8 & May 9 & May 10 \\
\hline Latitude & & $47^{\circ} 25^{\circ} \mathrm{N}$ & $48^{\circ} 30^{\circ} \mathrm{N}$ & $49^{\circ} 00^{\circ} \mathrm{N}$ & $49^{\circ} 30^{\circ} \mathrm{N}$ & $50^{\circ} 24^{\circ} \mathrm{N}$ \\
\hline Longitude & & $7^{\circ} 16^{\circ} \mathrm{W}$ & $8^{\circ} 54^{\circ} \mathrm{W}$ & $10^{\circ} 00^{\circ} \mathrm{W}$ & $10^{\circ} 51^{\circ} \mathrm{W}$ & $10^{\circ} 36^{\circ} \mathrm{W}$ \\
\hline SST & $\left({ }^{\circ} \mathrm{C}\right)$ & 12.15 & 12.18 & 12.11 & 12.54 & 13.29 \\
\hline $\mathrm{pCO}_{2}$ & $(\mathrm{ppm})$ & & 309 & 294 & 282 & 307 \\
\hline Air-sea $\mathrm{CO}_{2}$ flux & $\left(\mathrm{mgCm} \mathrm{m}^{-2} \mathrm{~d}^{-1}\right)$ & & -120 & -148 & -170 & -123 \\
\hline $\mathrm{PP}$ & $\left(\mathrm{mg} \mathrm{C} \mathrm{m}{ }^{-2} \mathrm{~d}^{-1}\right)$ & 410 & 1010 & 450 & 320 & 500 \\
\hline CAL & $\left(\mathrm{mgCm} \mathrm{m}^{-2} \mathrm{~d}^{-1}\right)$ & 520 & 320 & 210 & 150 & $<10$ \\
\hline $\mathrm{P}^{\mathrm{Th}}$ & $\left(\mathrm{dpm} \mathrm{m} \mathrm{m}^{-2} \mathrm{~d}^{-1}\right)$ & & $1492 \pm 241$ & $1112 \pm 165$ & $746 \pm 174$ & $708 \pm 141$ \\
\hline $\mathrm{P}-\mathrm{POC}^{\mathrm{Th}}$ & $\left(\mathrm{mgC} \mathrm{m}^{-2} \mathrm{~d}^{-1}\right)$ & & $323 \pm 99$ & $138 \pm 41$ & $81 \pm 15$ & $99 \pm 50^{\mathrm{a}}$ \\
\hline P-PIC ${ }^{\text {Th }}$ & $\left(\mathrm{mg} \mathrm{C} \mathrm{m} \mathrm{m}^{-2} \mathrm{~d}^{-1}\right)$ & & $84 \pm 29$ & $75 \pm 22$ & $30 \pm 7$ & $36 \pm 17^{\mathrm{a}}$ \\
\hline ThE & $(\%)$ & & $32 \pm 10$ & $31 \pm 9$ & $25 \pm 5$ & $20 \pm 10$ \\
\hline$T^{P}$ & (Days) & & $21 \pm 12$ & $25 \pm 12$ & $61 \pm 23$ & $30 \pm 14$ \\
\hline
\end{tabular}

a $\mathrm{PIC}$ and $\mathrm{POC}$ fluxes calculated using mean depth profiles of $\mathrm{POC} /{ }^{234} \mathrm{Th}^{\mathrm{P}}$ and $\mathrm{PIC} /{ }^{234} \mathrm{Th}^{\mathrm{P}}$ ratios obtained in this work.

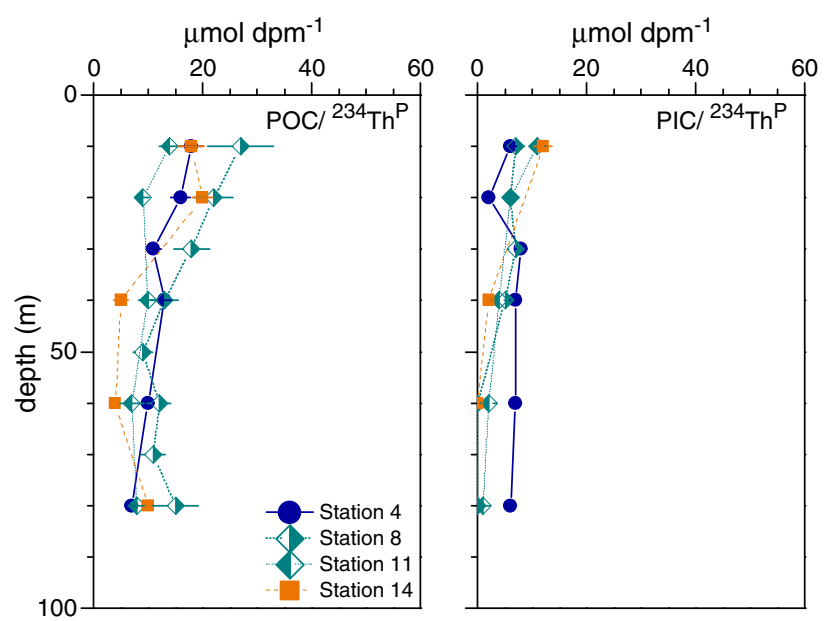

Fig. 4. Vertical profiles of particulate organic (POC, left, $\mu \mathrm{g} \mathrm{C} \mathrm{L}^{-1}$ ) and inorganic (PIC, right, $\mu \mathrm{g} \mathrm{C} \mathrm{L}{ }^{-1}$ ) carbon to particulate ${ }^{234} \mathrm{Th}$ ratios $\left(\mu \mathrm{mol} \mathrm{dpm}{ }^{-1}\right)$.

\subsection{Particle export during transition periods}

${ }^{234} \mathrm{Th}$, produced in seawater via the decay of its long-lived and highly soluble parent, Uranium-238 $\left({ }^{238} \mathrm{U}\right)$, is widely used as a tracer to quantify export fluxes and residence time of particles (Cochran and Masqué, 2003). Since ${ }^{234} \mathrm{Th}$ is highly particle-reactive, the clearance of ${ }^{234} \mathrm{Th}$ from surface waters is a direct indication of the removal rate of material on sinking particles from the upper ocean. Buesseler et al. (2006 and references therein) showed the robustness of this tracer as a proxy for estimating export of particulate carbon. In surface waters, ${ }^{234} \mathrm{Th}$ activities are the result of a balance between its continuous production from ${ }^{238} \mathrm{U}$, its decay, its removal onto rapidly sinking particles, and its transport by advection and diffusion. The temporal change in total ${ }^{234} \mathrm{Th}$ is expressed by the classical transport equation:

$\delta \mathrm{Th} / \delta \mathrm{t}=\lambda^{238} \mathrm{U}-\lambda^{234} \mathrm{Th}^{\mathrm{T}}-\mathrm{P}^{\mathrm{Th}}+\mathrm{V}$

where $\lambda$ is the decay constant of ${ }^{234} \mathrm{Th}\left(=0.0288 \mathrm{~d}^{-1}\right), \mathrm{P}^{\mathrm{Th}}$ is the net removal flux of ${ }^{234} \mathrm{Th}^{\mathrm{P}}$, and $\mathrm{V}$ is the sum of the advective/diffusive fluxes (Savoye et al., 2006 and references therein).
Measurements of dissolved and particulate ${ }^{234} \mathrm{Th}$ allow calculation of particle export fluxes and residence times. Although the use of non-steady-state modelling is recommended (Buesseler et al., 1992; Savoye et al., 2006; Schmidt et al., 2002a), steady state (SS) models of ${ }^{234}$ Th scavenging in the water column have been shown to provide adequate estimation of ${ }^{234} \mathrm{Th}$ fluxes, especially when sampling does not occur just after a high export event that depleted ${ }^{234} \mathrm{Th}$ stock (Schmidt et al., 2007; Tanaka et al., 1983). The major component driving ocean export flux of ${ }^{234} \mathrm{Th}$ is the SS term (Benitez-Nelson et al., 2000; Dunne et al., 1997). In this work the stations were visited only one time, and SS model is thus used: neglecting the transport of ${ }^{234}$ Th due to diffusion and advection, $\mathrm{P}^{\text {Th }}$ must balance the measured deficit relative to ${ }^{238} \mathrm{U}$, as:

$\mathrm{P}^{\mathrm{Th}}=\lambda\left({ }^{238} \mathrm{U}-{ }^{234} \mathrm{Th}^{\mathrm{T}}\right)$.

Residence times of particulate ${ }^{234} \mathrm{Th}\left(\mathrm{T}^{\mathrm{P}}\right)$ with respect to particle sinking is given by:

$\mathrm{T}^{\mathrm{P}}=\mathrm{Th}^{\mathrm{P}} / \mathrm{P}^{\mathrm{Th}}$.

Hereafter, particle residence time is assumed to be a substitute for ${ }^{234} \mathrm{Th}^{\mathrm{P}}$ residence time. Indeed, once ${ }^{234} \mathrm{Th}$ is scavenged onto particles, it can be assumed that its fate (other than decay) is the same as that of particles. Station 4 on the slope was excluded from the calculations as the above assumptions (negligible advection, SS model) would not hold: firstly this station presents a deep mixed layer, indicating high dynamic and probably advection related to strong slope currents (e.g. Huthnance et al., 2001); secondly the large deficit of ${ }^{234} \mathrm{Th} /$ ${ }^{238} \mathrm{U}$, even at the base of the profile at $80 \mathrm{~m}$, was ascribed to a former export event (see Section 3.4).

On the outer shelf of the North-Western European margin (stations 8, 11, 14 and 16; Table 1), $\mathrm{P}^{\text {Th }}$ values in May 2002 (708-1492 $\left.\mathrm{dpm} \mathrm{m}^{-2} \mathrm{~d}^{-1}\right)$ were comparable to values ( $>1000 \mathrm{dpm} \mathrm{m}^{-2} \mathrm{~d}^{-1}$ ) commonly reported during bloom situations in the North Atlantic (Buesseler et al., 1992; Hall et al., 2000). The spatial evolution of particulate ${ }^{234}$ Th fluxes showed a clear northward decrease. At the northern boundary of the 
transect, in the vicinity of the Goban Spur, $\mathrm{P}^{\mathrm{Th}}$ were lowered by a factor of about 2 (Table 1 ). This large decrease coincided with a simultaneous decrease in Chl-a, CAL and $\mathrm{L}_{\mathrm{wn}}(555)$. All parameters agreed to indicate an ecosystem becoming less efficient in particle production and export northward.

Mean particle residence times in upper waters are comprised between 21 and 25 days in the southern area and 30 and 61 days in the north end of the transect (Table 1). These values are similar to those reported for the North Atlantic margin (Buesseler et al., 1992; Hall et al., 2000; Moran and Smith, 2000; Schmidt et al., 2002b) and reflect a bloom situation with efficient export fluxes. However, as previously observed for other variables, there is also a northward pattern with an increase of particle residence times, reflecting a decrease in export fluxes.

\subsection{Implication for carbon export during E. huxleyi bloom}

The export fluxes of POC ( $\left.\mathrm{P}-\mathrm{POC}^{\mathrm{Th}}\right)$ from surface waters can be calculated using the particulate ${ }^{234} \mathrm{Th}$ flux $\left(\mathrm{P}^{\mathrm{Th}}\right)$ and the $\mathrm{POC} /{ }^{234} \mathrm{Th}$ ratio of particles as:

$\mathrm{P}-\mathrm{POC}^{\mathrm{Th}}=\mathrm{P}^{\mathrm{Th}}\left(\mathrm{POC} /^{234} \mathrm{Th}^{\mathrm{P}}\right)$

We have used the POC $/{ }^{234} \mathrm{Th}^{\mathrm{P}}$ of suspended particles, although a recommendation on this method was to use $\mathrm{POC} /{ }^{234} \mathrm{Th}^{\mathrm{P}}$ of large particles (see the review by Buesseler et al., 2006). The basic assumption was the particle export flux was classically supposed to be dominated by large sinking particles, which tend to have lower $\mathrm{POC} /{ }^{234} \mathrm{Th}^{\mathrm{P}}$ ratios (Burd et al., 2000). Note that Cochran et al. (1995), Foster and Shimmield (2002), Hall et al. (2000) and Moran and Smith (2000) have used $\mathrm{POC} /{ }^{234} \mathrm{Th}^{\mathrm{P}}$ of SPM to calculate POC fluxes in different regions of the Atlantic Ocean. More recent publications have debated the $\mathrm{POC} /{ }^{234} \mathrm{Th}^{\mathrm{P}}$ ratio in relation to particle size or plankton community composition and particle export of organic carbon and ${ }^{234} \mathrm{Th}$ (Burd et al., 2007). Hung and Gong (2010) and Hung et al. (2010) have suggested that the $\mathrm{POC} /{ }^{234} \mathrm{Th}$ ratios traditionally derived from large ( $>50 \mu \mathrm{m}$ ) pump-collected particles may not accurately reflect the majority of sinking particles and that the contribution of particles $<50 \mu \mathrm{m}$ to the settling flux is larger than previously thought.

This could be related to the pelagic community structure. In the present experiment, surface waters did comprise a large fraction of coccolithophores. Despite the small size of E. huxleyi $(5-7 \mu \mathrm{m})$, the number of cells during bloom events usually outnumbers those of all other species combined, frequently accounting for 80 or $90 \%$ or more of the total number of phytoplankton cells in the water (Brown and Yoder, 1994; Holligan et al., 1993). Therefore, E. huxleyi-related particles may settle out of the euphotic zone directly through aggregation, that could be promoted by TEP, or indirectly as zooplankton faecal pellets (Engel et al., 2009). This assumption is in agreement with recent observations in the Sargasso Sea (Brew et al., 2009) and modelling studies (Richardson and Jackson, 2007); these authors concluded that, although small in size, pico-plankton may contribute strongly to particle export in proportion to their high contribution to net primary production (e.g. Uitz et al., 2010).

A specific feature of coccolithophore blooms is also to promote the export of $\mathrm{CaCO}_{3}$ in addition to POC. Therefore, we calculated in the same way as for POC the export fluxes of PIC (P-PIC ${ }^{\mathrm{Th}}$ ) from the surface waters using the particulate ${ }^{234} \mathrm{Th}$ flux and the PIC/ ${ }^{234} \mathrm{Th}$ ratio of particles as:

$\mathrm{P}-\mathrm{PIC} C^{\mathrm{Th}}=\mathrm{P}^{\mathrm{Th}}\left(\mathrm{PIC} /{ }^{234} \mathrm{Th}^{\mathrm{P}}\right)$

Not surprisingly, POC export fluxes were the highest in the upper 0-20 m waters (Fig. 5), and had negligible values in the $70-80 \mathrm{~m}$ layer. This decrease with depth followed the vertical distribution of POC (Fig. 3c). Total POC fluxes decreased northward from 323 to $81 \mathrm{mg} \mathrm{C} \mathrm{m}^{-2} \mathrm{~d}^{-1}$. These POC fluxes fall into the range observed for the North Atlantic during the spring bloom (Buesseler et al., 1992; Hall et al., 2000). PIC fluxes exhibited the same pattern with depth, although P-PIC ${ }^{\text {Th }}$ values were lower and became negligible below $40 \mathrm{~m}$, reflecting the near absence of PIC in depth. Total PIC fluxes decreased also northward from 84 to $30 \mathrm{mg} \mathrm{C} \mathrm{m}^{-2} \mathrm{~d}^{-1}$.

Buesseler (1998) defined ThE as the ratio of POC export derived from ${ }^{234} \mathrm{Th}$ to PP and showed that most oceanic regions are characterised by low ThE (ThE $<5-10 \%$ ), except during blooms like those observed during the North Atlantic Bloom Experiment (NABE) (20-79\%, Buesseler et al., 1992) or during more episodic export pulses (Northeast Polynya, Cochran et al., 1995). Foster and Shimmield (2002) adopted a Lagrangian strategy in the northern North Sea to investigate particle export during a coccolithophore bloom development. Their POC and PIC fluxes ranged from 110 to $576 \mathrm{mg} \mathrm{C} \mathrm{m}^{-2} \mathrm{~d}^{-1}$ and 0 to $240 \mathrm{mg} \mathrm{C} \mathrm{m}^{-2} \mathrm{~d}^{-1}$ respectively. The maximum fluxes, dominated by phytodetritus, mainly followed the peak in primary production and the maximum coccolithophore cell abundance within a few days. ThE increased during this Lagrangian experiment, from 7 to $96 \%$ (Foster and Shimmield, 2002). These authors underlined also the rapid and

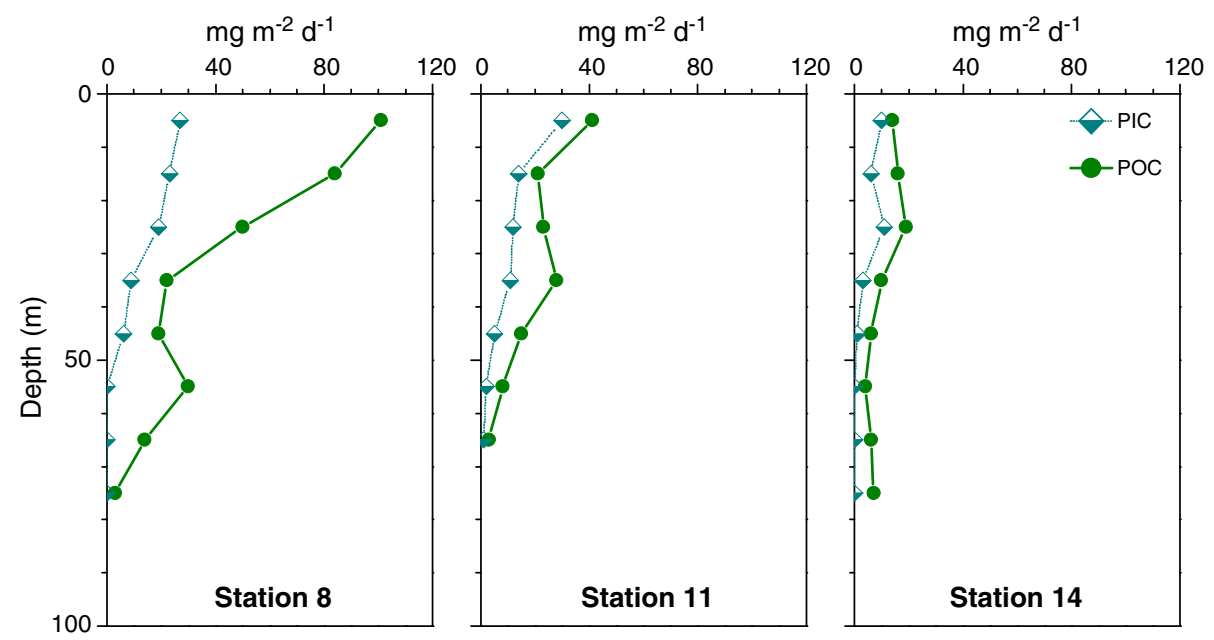

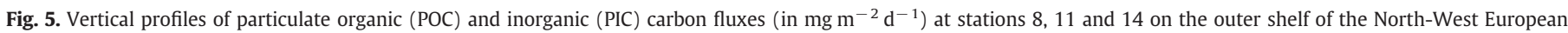
margin. Fluxes are calculated for each 10-m layer from surface to $80 \mathrm{~m}$; total POC and PIC fluxes (in $\mathrm{mg} \mathrm{m}^{-2} \mathrm{~d}^{-1}$ ) in Table 1 correspond to the sum. 


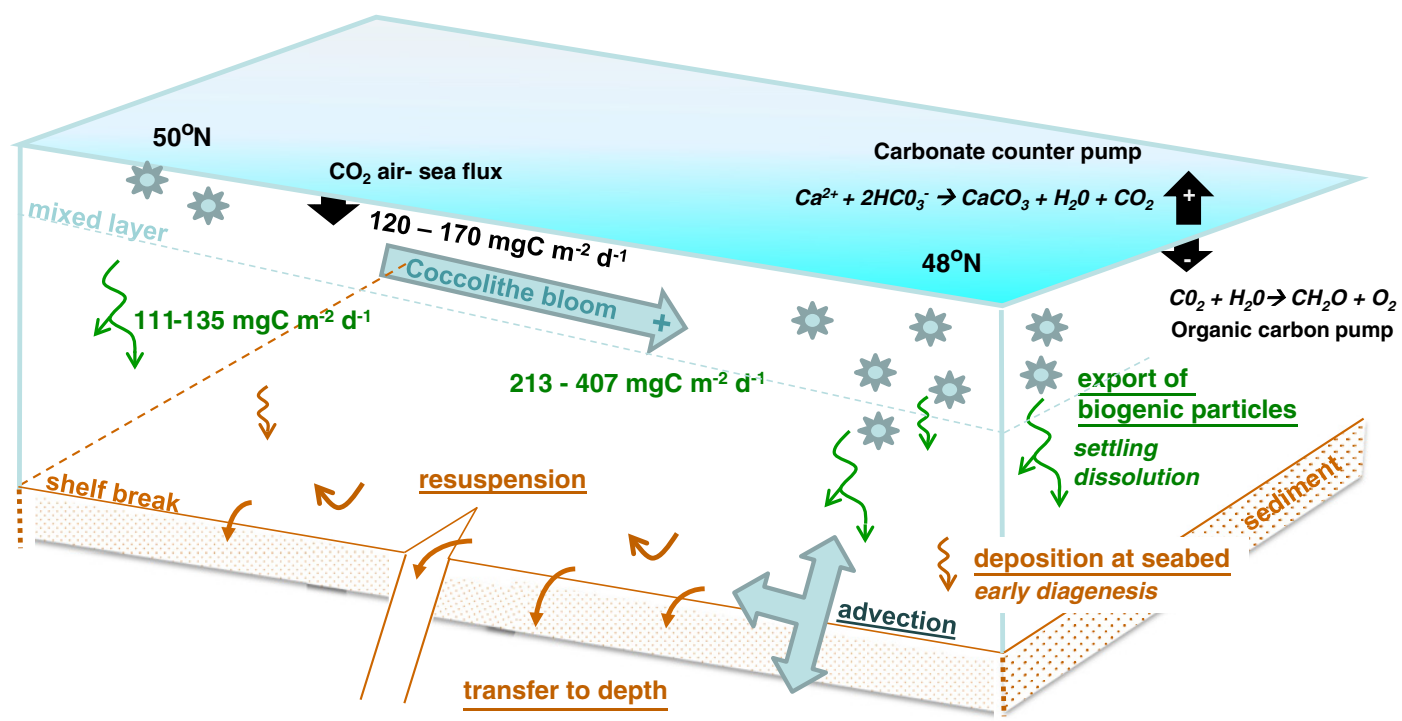

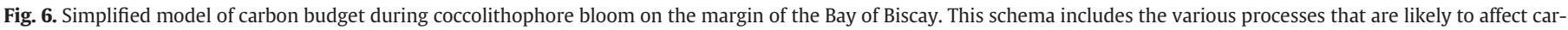

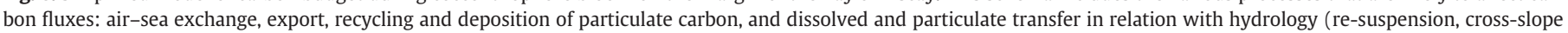
exchange). Values correspond to the present work (Table 1), total carbon export corresponding to the sum of POC and PIC fluxes.

strong response of export with biological activity. Surface waters of the outer shelf of the North-West European margin followed these general patterns, with ThE decreasing from $32 \%$ in the southern and productive sites to $17 \%$ in the northern site (station 16 ) of the survey (Table 1 ).

\section{Conclusions}

During the BG02/11 cruise, surface waters were sampled along a transect on the outer shelf of the North-West European margin to investigate particulate export in relation with the occurrence of coccolithophores. Integrated rates of PP (320-1010 $\left.\mathrm{mg} \mathrm{C} \mathrm{m}^{-2} \mathrm{~d}^{-1}\right)$ and CAL (10-320 mg C m $\mathrm{m}^{-2} \mathrm{~d}^{-1}$ ) were consistent with values reported during coccolithophore blooms in the North Atlantic waters. Remotely sensed Chl-a and $\mathrm{L}_{\mathrm{wn}}(555)$ indicated a distinct decrease in coccolithophore bloom northward, from the La Chapelle Bank to the Goban Spur. POC and PIC export fluxes and the ratio of POC export to PP, derived from ${ }^{234} \mathrm{Th}$, showed a similar northward decrease (Fig. 6). Despite the high calcification rates at the southernmost stations, surface waters are a net sink of atmospheric $\mathrm{CO}_{2}$ during the cruise. These results tend to demonstrate the positive impact of coccolithophore bloom on the efficiency of the ecosystem to export carbon to deep ocean.

Although the annual mean area covered by coccolithophorid blooms was estimated to be about $13 \times 10^{6} \mathrm{~km}^{2}$ in North Atlantic region $\left(40^{\circ}-70^{\circ} \mathrm{N}\right.$; Brown and Yoder, 1994$)$, there are only few studies in the Bay of Biscay. Lampert et al. (2002) have demonstrated the occurrence of such blooms on the French continental waters, that was related to large river inputs (especially from the Gironde estuary). But little is known about the sedimentation of this production, generally restricted to waters over the continental shelves and at the shelf break. The present work confirms the efficiency of coccolithophore bloom to export carbon from surface waters. However the fate of this settling matter is complex (Fig. 6): settled particles could be partly recycled in the water column. Only a fraction is likely to reach the seafloor, where early diagenesis and dissolution also occur. Once at the water-sediment interface, this newly-deposited material could be resuspended by currents. Based on a sediment trap investigation on the slope of the South Bay of Biscay, Beaufort and Heussner (1999) showed that lateral transport of coccoliths resuspended from shelf and/or upper slope sediments seems to be the dominant transfer process to depth on the North-Eastern Atlantic slope; the presence of numerous canyons along the continental margin of the Bay of Biscay may favour this transfer. From the clear seasonal succession observed in the species composition, these authors have postulated that this deposition/resuspension/transport sequence is rapid (presumably less than a few months). Suykens et al. (2011) have in fact observed high-resuspension of fresh and fine material on the North Bay of Biscay and transport towards the Celtic Sea with a northward along slope current (Pingree and Le Cann, 1995). Based on the present work and by the above synthesis, we provide a conceptual model for carbon budget during coccolithophore bloom along the margin of the Bay of Biscay (Fig. 6): most fluxes still need to be quantified.

In order to provide an accurate estimate of the capacity of the ocean to store organic and inorganic carbon (Fig. 6), it is essential to understand the physical, chemical and biological controls on the present marine ecosystem and ocean carbon dynamics, including a better understanding of the efficiency of marine ecosystems in carbon export, to predict its future evolution. Coccolithophores are likely to play key roles in the global carbon cycles through primary production, calcification and carbon export, the main drivers of the biological $\mathrm{CO}_{2}$ pump. Coccolithophore blooms result in the loss of both POC and PIC to the deeper ocean. Coccolithophores are considered to be by far the dominant contributors to pelagic calcification that has been evaluated globally ( $\left.1.6 \pm 0.3 \mathrm{Pg} \mathrm{PIC}^{-1}\right)$ by Balch et al. (2007) based on remote sensing data, in general agreement with previous estimates by Milliman et al. (1999). At present, uncertainties remain regarding the bloom development of coccolithophores, and contribution to the export of $\mathrm{POC}$ and $\mathrm{CaCO}_{3}$ to depth. Attempts to estimate carbon production and export have been done recently (Beaufort and Heussner, 1999; Broerse et al., 2000; Fernández et al., 1993; Foster and Shimmield, 2002; Graziano et al., 2000; Gregg and Casey, 2007; Lipsen et al., 2007; Ziveri et al., 2007), but, to our knowledge, this is only the second study that uses ${ }^{234} \mathrm{Th}$ as a proxy for POC and PIC export specifically during coccolithophore blooms. However, improvements in the estimation of POC and PIC export during coccolithophore blooms are needed not only to understand the present $\mathrm{C} / \mathrm{P}$ ratio, but also to help understand future sequestration of organic and inorganic carbon to the deep ocean.

\section{Acknowledgements}

The crew of the R/V Belgica are gratefully acknowledged for their help with sampling. This study was financially supported by the Belgian Federal Office for Scientific, Technical and Cultural Affairs (OSTC) "Role of Oceanic Production and Dissolution of Calcium 
Carbonate in Climate Change" (CCCC, Contract Nos. EV/11/5A, EV/03/ 5B, EV/06/5C) project. SS acknowledges support from the French Institut National des Sciences de l'Univers (INSU) through a travel grant for cruise participation (soutien de campagne à la mer). AVB and $\mathrm{BD}$ are research associates at the Fonds National de la Recherche Scientifique. Near-real time satellite data were provided by the UK NERC Earth Observation Data Acquisition and Analysis Service.

\section{References}

Balch, W.M., Drapeau, D., Bowler, B., Booth, E., 2007. Prediction of pelagic calcification rates using satellite measurements. Deep-Sea Res. II 54, 478-495.

Beaufort, L., Heussner, S., 1999. Coccolithophorids on the continental slope of the Bay of Biscay - production, transport and contribution to mass fluxes. Deep-Sea Res. II 46, 2147-2174.

Benítez-Nelson, C.R., Buesseler, K.O., Crossin, G., 2000. Upper ocean carbon export, horizontal transport, and vertical eddy diffusivity in the southwestern Gulf of Maine. Cont. Shelf Res. 20, 707-736.

Brew, H.S., Moran, S.B., Lomas, M.W., Burd, A.B., 2009. Plankton community composition, organic carbon and thorium-234 particle size distributions, and particle export in the Sargasso Sea. J. Mar. Syst. 67, 845-868.

Broerse, A.T.C., Ziveri, P., van Hinte, J.E., Honjo, S., 2000. Coccolithophore export production, species composition, and coccolith- $\mathrm{CaCO}_{3}$ fluxes in the NE Atlantic $\left(34^{\circ} \mathrm{N} 21^{\circ} \mathrm{W}\right.$ and $48^{\circ} \mathrm{N} 21^{\circ} \mathrm{W}$ ). Deep-Sea Res. II 47, 1877-1905.

Brown, C.W., Yoder, J.A., 1994. Coccolithophorid blooms in the global ocean. J. Geophys. Res. 99, 7467-7482.

Buesseler, K.O., 1998. The decoupling of production and particulate export in the surface ocean. Global Biogeochem. Cycles 12, 297-310.

Buesseler, K.O., Bacon, M.P., Cochran, J.K., Livingston, H.D., 1992. Carbon and nitrogen export during the JGOFS North Atlantic Bloom experiment estimated from ${ }^{234} \mathrm{Th}$ : ${ }^{238} \mathrm{U}$ disequilibria. Deep-Sea Res. A 39, 1115-1137.

Buesseler, K.O., Benítez-Nelson, C.R., Moran, S.B., Burd, A., Charette, M., Cochran, J.K., Coppola, L., Fisher, N.S., Fowler, S.W., Gardner, W.D., Guo, L.D., Gustafsson, O., Lamborg C., Masque, P., Miquel, J.C., Passow, U., Santschi, P.H., Savoye, N., Stewart, G., Trull, T., 2006. An assessment of particulate organic carbon to thorium-234 ratios in the ocean and their impact on the application of ${ }^{234} \mathrm{Th}$ as a POC flux proxy. Mar. Chem. $100,213-233$.

Burd, A.B., Moran, S.B., Jackson, G.A., 2000. A coupled adsorption-aggregation model of the POC $/{ }^{234}$ Th ratio of marine particles. Deep-Sea Res. I 47, 103-120.

Burd, A.B., Jackson, G.A., Moran, S.B., 2007. The role of the particle size spectrum in estimating POC fluxes from ${ }^{234} \mathrm{Th} /{ }^{238} \mathrm{U}$ disequilibrium. Deep-Sea Res. I 54, 897-918.

Burkill, P.H., Archer, S.D., Robinson, C., Nightingale, P.D., Groom, S.B., Tarran, G.A., Zubkov, M.V., 2002. Dimethyl sulphide biogeochemistry within a coccolithophore bloom (DISCO): an overview. Deep-Sea Res. II 49, 2863-2885.

Cochran, J.K., Masqué, P., 2003. Short-lived U/Th series radionuclides in the ocean: tracers for scavenging rates, export fluxes and particle dynamics. In: Bourdon, B., Henderson, G.M., Lundstrom, C.C., Turner, S.P. (Eds.), Uranium-Series Geochemistry: Rev. Mineral. Geochem., 52, pp. 461-492.

Cochran, J.K., Barnes, C., Achman, D., Hirschberg, D.J., 1995. Thorium-234/Uranium-238 disequilibria as an indicator of scavenging rates and particulate organic carbon fluxes in the Northeast Water Polynya, Greenland. J. Geophys. Res. 100, 4399-4410.

Dunne, J.P., Murray, J.W., Young, J., Balistrieri, L.S., Bishop, J., 1997. ${ }^{234} \mathrm{Th}$ and particle cycling in the central equatorial Pacific. Deep-Sea Res. II 44, 2049-2083.

Engel, A., Szlosek, J., Abramson, L., Liu, Z., Lee, C., 2009. Investigating the effect of ballasting by $\mathrm{CaCO}_{3}$ in Emiliania huxleyi: I. Formation, settling velocities and physical properties of aggregates. Deep-Sea Res. II 56, 1396-1407.

Fernández, E., Boyd, P., Holligan, P.M., Harbour, D.S., 1993. Production of organic and inorganic carbon within a large-scale coccolithophore bloom in the northeast Atlantic Ocean. Mar. Ecol. Prog. Ser. 97, 271-285.

Foster, J.M., Shimmield, G.B., 2002. ${ }^{234}$ Th as a tracer of particle flux and POC export in the northern North Sea during a coccolithophore bloom. Deep-Sea Res. II 49 2965-2977.

Graziano, L.M., Balch, W.M., Drapeau, D., Bowler, B.C., Vaillancourt, R., Dunford, S., 2000 Organic and inorganic carbon production in the Gulf of Maine. Cont. Shelf Res. 20, 685-705.

Gregg, W.W., Casey, N.W., 2007. Modeling coccolithophores in the global oceans. DeepSea Res. II 54, 447-477.

Groom, S.B., Holligan, P.M., 1987. Remote sensing of coccolithophore blooms. Adv. Space Res. 7, 73-78.

Hall, I.R., Schmidt, S., McCave, I.N., Reyss, J.-L., 2000. Particulate matter distribution and ${ }^{234} \mathrm{Th} /{ }^{238} \mathrm{U}$ disequilibrium along the Northern Iberian Margin: implication for particulate organic carbon export. Deep-Sea Res. I 47, 557-582.

Harlay, J., Borges, A.V., Van Der Zee, C., Delille, B., Godoï, R.H.M., Schiettecatte, L.-S., Roevros, N., Aerts, K., Lapernat, P.-E., Rebreanu, L., Groom, S., Daro, M.-H., Van Grieken, R., Chou, L., 2010. Biogeochemical study of a coccolithophore bloom in the northern Bay of Biscay (NE Atlantic Ocean) in June 2004. Prog. Oceanogr. 86, 317-336.

Holligan, P.M., Viollier, M., Harbour, D.S., Camus, P., Champagne-Philippe, M., 1983. Satellite and ship studies of coccolithophore production along a continental shelf edge. Nature 304, 339-342.

Holligan, P.M., Fernández, E., Aiken, W., Balch, W.M., Boyd, P.W., Burkill, P.H., Finch, M., Groom, S.B., Malin, G., Muller, K., Purdie, D.A., Robinson, C., Trees, C.C., Turner, S.M., van der Wal, P., 1993. A biogeochemical study of the coccolithophore, Emiliania huxleyi, in the North Atlantic. Global Biogeochem. Cycles 7, 879-900.

Hung, C.-C., Gong, G.C., 2010. POC $/{ }^{234}$ Th ratios in particles collected in sediment traps in the northern South China Sea. Estuar. Coast. Shelf Sci. 88, 303-310.

Hung, C.-C., Xu, C., Santschi, P.H., Zhang, S.-J., Schwehr, K.A., Quigg, A., Guo, L., Gong, G.-C., Pinckney, J.L., Long, R.A., Wei, C.-L., 2010. Comparative evaluation of sediment trap and ${ }^{234}$ Th-derived POC fluxes from the upper oligotrophic waters of the Gulf of Mexico and the subtropical northwestern Pacific Ocean. Mar. Chem. 121, 132-144.

Huthnance, J.M., Coelho, H., Griffiths, C.R., Knight, P.J., Rees, A.P., Sinha, B., Vangriesheim, A., White, M., Chatwin, P.G., 2001. Physical structures, advection and mixing in the region of Goban spur. Deep-Sea Res. II 48, 2979-3021.

Joint, I., Wollast, R., Chou, L., Batten, S., Elskens, M., Edwards, E.S., Hirst, A., Burkill, P.H Groom, S.B., Gibb, S.W., Miller, A., Hydes, D.J., Dehairs, F., Antia, A.N., Barlow, R., Rees, A., Pomroy, A., Brockmann, U., Cimmings, D., Lampitt, R., Loijens, M., Mantoura, F., Miller, P., Raabe, T., Alvarez-Salgado, X., Stelfox, C., Woolfenden, J., 2001. Pelagic production at the Celtic Sea shelf break. Deep-Sea Res. 48, 3049-3081.

Lampert, L., Quéguiner, B., Labasque, T., Pichon, A., Lebreton, N., 2002. Spatial variability of phytoplankton composition and biomass on the eastern continental shelf of the Bay of Biscay (north-east Atlantic Ocean). Evidence for a bloom of Emiliania huxleyi (Prymnesiophyceae) in spring 1998. Cont. Shelf Res. 22, 1225-1247.

Lipsen, M.S., Crawford, D.W., Gower, J., Harisson, P.J., 2007. Spatial and temporal variability in coccolithophore abundance and production of PIC and POC in the NE subarctic Pacific during El Niño (1998), El Niña (1999) and 2000. Prog. Oceanogr. 75 304-325.

Marañon, E., González, N., 1997. Primary production, calcification and macromolecular synthesis in a bloom of the coccolithophore Emiliania huxleyi in the North Sea. Mar. Ecol. Prog. Ser. 157, 61-77.

McIntyre, A., Be, A.W.H., 1967. Modern coccolithophores from the Atlantic Ocean-I Placoliths and cyrtoliths. Deep-Sea Res. 14, 561-597.

Milliman, J.D., Troy, P.J., Balh, W.M., Adams, A.K., Li, Y.-H., MacKenzie, F.T., 1999. Biologically-mediated dissolution of calcium carbonate above the chemical lysocline? Deep-Sea Res. I 46, 1653-1669.

Moran, S.B., Smith, J.N., 2000. ${ }^{234}$ Th as a tracer of scavenging and particle export in the Beaufort Sea. Cont. Shelf Res. 20, 153-167.

Nanninga, H.J., Tyrrell, T., 1996. Importance of light for the formation of algal blooms by Emiliania huxleyi. Mar. Ecol. Prog. Ser. 136, 195-203.

Padin, X.A., Navarro, G., Gilcoto, M., Rios, A.F., Pérez, F.F., 2009. Estimation of air-sea $\mathrm{CO}_{2}$ fluxes in the Bay of Biscay based on empirical relationships and remotely sensed observations. J. Mar. Syst. 75, 280-289.

Pingree, R.D., Le Cann, B., 1995. Structure, strength and seasonality of the slope currents in the Bay of Biscay region. J. Mar. Biol. Assoc. U. K. 70, 857-885.

Richardson, T., Jackson, G., 2007. Small phytoplankton and carbon export from the surface ocean. Science 315, 838-840.

Robertson, J.E., Robinson, C., Turner, D.R., Holligan, P., Watson, A.J., Boyd, P., Fernandez, E., Finch, M., 1994. The impact of a coccolithophore bloom on oceanic carbon uptake in the northeast Atlantic during summer 1991. Deep-Sea Res. I 41, 297-314.

Rutgers van der Loeff, M., Sarin, M.M., Baskaran, M., Benítez-Nelson, C., Buesseler, K. Charette, M., Dai, M., Gustafsson, Ö., Masque, P., Morris, P., Rodriguez y Baena, A. Savoye, N., Schmidt, S., Vöge, I., Waples, J., 2006. A review of present techniques and methodological advances in analyzing ${ }^{234} \mathrm{Th}$ in aquatic systems. Mar. Chem. $100,190-212$.

Savoye, N., Benitez-Nelson, C., Burd, A., Cochran, K., Charette, M., Buesseler, K.O., Jackson, G., Roy-Barman, M., Schmidt, S., Elskens, M., 2006. ${ }^{234}$ Th sorption and export models in the water column: a review. Mar. Chem. 100, 213-233.

Schmidt, S., Reyss, J.-L., 2000. Improvement in radiochemical and $\gamma$-counting procedures for the determination of ${ }^{234} \mathrm{Th}$ in seawater. Radiochim. Acta 88, 459-463.

Schmidt, S., Andersen, V., Belviso, S., Marty, J.-C., 2002a. Strong seasonality in particle dynamics of north-western Mediterranean sea surface waters (JGOFS France DYFAMED time-series station) as revealed by ${ }^{234} \mathrm{Th} /{ }^{238} \mathrm{U}$. Deep-Sea Res. I 49, 1507-1518.

Schmidt, S., Chou, L., Hall, I.R., 2002b. Particle residence times in surface waters over the north-western Iberian Margin: comparison of pre-upwelling and winter periods. J. Mar. Syst. 32, 3-11.

Schmidt, S., Belviso, S., Wasman, P. Thouzeau, G., Stefels, J., 2007. Vernal sedimentation trends in north Norwegian fjords: temporary anomaly in ${ }^{234} \mathrm{Th}$ particulate fluxes related to Phaeocystis proliferation. Biogeochemistry 83, 235-244.

Suykens, K., Delille, B., Chou, L., De Bodt, C., Harlay, J., Borges, A.V., 2010. Dissolved inorganic carbon dynamics and air-sea carbon dioxide fluxes during coccolithophore blooms in the Northwest European continental margin (northern Bay of Biscay). Global Biogeochem. Cycles 24. doi:10.1029/2009GB003730.

Suykens, K., Schmidt, S., Delille, B., Harlay, J., Chou, L., De Bodt, C., Fagel, N., Borges, A.V., 2011. Benthic remineralization in the northwest European continental margin (northern Bay of Biscay). Cont. Shelf Res. 31, 644-658.

Tanaka, N., Takeda, Y., Tsunogai, S., 1983. Biological effect on removal of Th-234, Po210 and $\mathrm{Pb}-210$ from surface water in Funkai Bay, Japan. Geochim. Cosmochim. Acta $47,1783-1790$.

Uitz, J., Claustre, H., Gentili, B., Stramski, D., 2010. Phytoplankton class-specific primary production in the world's oceans: seasonal and interannual variability from satellite observations. Global Biogeochem. Cycles 24, GB3016. doi:10.1029/2009GB003680.

Ziveri, P., de Bernardi, B., Baumannd, K.-H., Stolle, H.M., Mortyna, P.G., 2007. Sinking of coccolith carbonate and potential contribution to organic carbon ballasting in the deep ocean. Deep-Sea Res. II 54, 659-675. 